\title{
PERUBAHAN TINGKAT LIKUIDITAS SAHAM DAN ABNORMAL RETURN YANG DIPENGARUHI OLEH PERISTIWA PEMECAHAN SAHAM
}

\author{
Achmad Yusup Sulaiman ${ }^{1}$; Hidayat Darwis ${ }^{2}$ \\ ${ }^{1}$ STIE Muhammadiyah Jakarta, achmadyusufsulaiman@gmail.com \\ ${ }^{2}$ STIE Muhammadiyah Jakarta, hidayat201161@gmail.com
}

\begin{abstract}
ABSTRAK
Penelitian ini dilakukan untuk mengetahui signifikansi perubahan pada likuiditas saham dan abnormal return saham sebelum dan sesudah peristiwa pemecahan saham. Teknik sampel yang digunakan dalam penelitian ini adalah purposive sampling dan kriteria yang digunakan antara lain emiten tidak melakukan corporate action lain pada saat bersamaan dengan stock split. Sampel yang digunakan dalam penelitian ini sejumlah 28 perusahaan. Hasil dari penelitian ini menunjukkan bahwa peristiwa pemecahan saham berpengaruh signifikan terhadap tingkat likuiditas saham. Sedangkan untuk abnormal return saham, pemecahan saham tidak berpengaruh artinya secara keseluruhan, pemecahan saham tidak mempengaruhi tingkat abnormal return saham.
\end{abstract}

Kata Kunci: Pemecahan Saham, Likuiditas, Trading Volume Activity, Abnormal Return.

\begin{abstract}
This study was conducted to determine the significance of changes in stock liquidity and abnormal stock returns before and after the stock split. The sample technique used in this study was purposive sampling and the criteria used included the issuer not taking other corporate actions at the same time as the stock split. The samples used in this study were 28 companies. The results of this study indicate that stock split events have a significant effect on the level of stock liquidity. Whereas for abnormal stock returns, stock splits do not affect the overall meaning, stock splits do not affect the level of abnormal stock returns.
\end{abstract}

Keywords: Stock Split, Liquidity, Trading Volume Activity, Abnormal Return.

\section{PENDAHULUAN}

Peningkatan aktivitas perekonomian dipengaruhi oleh beberapa faktor, salah satu faktor yang berperan besar adalah Pasar Modal. Apabila sebuah perusahaan membutuhkan dana untuk ekspansi pasar, atau apabila ada investor yang ingin mendapatkan imbal hasil dari dana menganggur yang dipunya, maka Pasar Modal dapat memberi solusi atas masalah-masalah tersebut.

Salah satu cara yang dapat dilakukan perusahaan untuk menambah daya tarik saham adalah melalui kebijakan pemecahan saham (stock split). Secara teoritis, ada dua teori yang melandasi alasan mengapa 


\section{JURNAL AKUNTANSI, Vol. 8, No. 2, November (2019)}

banyak perusahaan melakukan corporate action berupa pemecahan saham atau stock split. Kedua teori tersebut adalah Trading Range Theory dan Signaling Theroy.

Trading Range Theory menyatakan harga saham yang terlalu tinggi (over priced) menyebabkan kurang aktifnya saham tersebut diperdagangkan (Izza, 2016:33). Pemecahan saham dilakukan dalam rangka menyesuaikan harga saham ke dalam optimal range sehingga akan meningkatkan jumlah peminat saham, dan pada akhirnya meningkatkan jumlah investor yang memperdagangkan saham sehingga volume perdagangan saham pun meningkat.

Volume perdagangan suatu saham di pasar modal dapat diukur melalui TVA (Trading Volume Activity). TVA dihitung melalui perbandingan antara jumlah saham yang diperdagangkan pada suatu waktu tertentu dengan jumlah seluruh saham yang beredar pada waktu tersebut.

Astuti (2015:10-11) menyatakan bahwa prinsip dari signaling theory adalah bahwa setiap tindakan mengandung informasi karena adanya asymetric information.Asymetric information merupakan kondisi dimana suatu pihak memiliki informasi yang lebih banyak daripada pihak lain. Signaling theorymendorong perusahaan untuk melakukan pemecahan saham karena adanya kesempatan investasi serta prospek perusahaan yang baik di masa depan Hartono (2010:561-562).

Untuk melihat apakah terdapat reaksi pasar terhadap peristiwa pemecahan saham, dapat digunakan abnormal return sahamnya. Terjadinya perubahan pada abnormal return saham diartikan sebagai reaksi pasar. Abnormal return adalah selisih antara return yang sesungguhnya terjadi dengan returnekspektasi (Jogiyanto, 2015:647).

Di kalangan para peneliti, peristiwa pemecahan saham ini masih menjadi sebuah puzzle atau tekateki yang masih menyisakan berbagai pertanyaan. Tidak sedikit penelitian yang dilakukan, namun hasil penelitian yang didapatkan masih sangat bervariasi dan berakhir dengan kesimpulan yang berbeda-beda.

Penelitian yang dilakukan oleh Ellen Rusliati dan Esti Nur Farida (2010:172)terhadap perusahaanperusahaan yang terdaftar di Bursa Efek Indonesia yang melakukan pemecahan saham selama periode 2006-2008 menunjukkan bahwa terdapat pengaruh stock split terhadap tingkat likuiditas dan abnormal return saham.

Penelitian oleh Tiwi Nurjannati Utami, Ghozali Maski, dan Syafe'i Idrus (2009) berkesimpulan bahwa peristiwa pemecahan saham tidak memiliki pengaruh terhadap likuiditas saham dan abnormal return. Hasil uji beda menunjukkan bahwa tidak terdapat perubahan yang signifikan pada abnormal return saham sebelum dan sesudah pemecahan saham, dan demikian pula pada likuiditas saham.

Keberagaman hasil penelitian ini kemungkinan disebabkan oleh beberapa faktor, seperti perbedaan periode pengamatan, kurang spesifiknya ruang lingkup penelitian serta perbedaan proksi yang digunakan sebagai indikator pada masing-masing variable.Oleh karena itu, diambillah judul penelitian"Perubahan Tingkat Likuiditas Saham dan Abnormal Return yang Dipengaruhi oleh Peristiwa Pemecahan Saham (Stock Split) di Bursa Efek Indonesia Tahun 2017-2018”.

\section{KAJIAN LITERATUR}

\section{Saham}

Darmadji dan Fakhruddin (2012:5) mengatakan bahwa "Saham (stock) merupakan tanda penyertaan atau pemilikan seseorang atau badan dalam suatu perusahaan atau perseroan terbatas. Saham berwujud selembar kertas yang menerangkan bahwa pemilik kertas tersebut adalah pemilik perusahaan yang menerbitkan surat berharga tersebut".

Menurut Tandelilin (2010:32), saham terbagi dalam 2 (dua) jenis, yaitu:

a. Saham Biasa (Common Stock) menyatakan kepemilikan suatu perusahaan.Saham biasa adalah sertifikat yang menunjukkan bukti kepemilikan suatuperusahaan.

b. Saham Preferen (Preferred Stock) merupakan satu jenis sekuritas ekuitasyang berbeda dalam beberapa hal dengan saham biasa. 


\section{JURNAL AKUNTANSI, Vol. 8, No. 2, November (2019)}

\section{Likuiditas Saham}

Menurut Bodie et. al. dalam Rusliati dkk. (2010), likuiditas saham adalah seberapa mudah dan cepat suatu aset dapat dijual dan berada dekat dengan nilai wajarnya. Dari pernyataan tersebut, terdapat dua indikator utama likuiditas suatu saham, yaitu pertama saham dapat dijual dengan mudah dan cepat dan yang kedua dijual dengan harga yang dekat dengan nilai wajarnya.

Likuiditas saham dapat diukur dengan menggunakan proksiTrading Volume Activity (TVA). TVA diukur dengan membandingkan antara jumlah saham yang diperdagangkan pada periode tertentu dengan jumlah seluruh saham beredar pada periode tersebut. Semakin tinggi TVA suatu saham, maka saham tersebut semakin likuid.

\section{Abnormal Return}

Abnormal return pada umumnya sering digunakan untuk mengukur reaksi pasar dan efisiensi pasar.Abnormal return merupakan selisih dari imbal hasil yang sesungguhnya (actual return) terhadap imbal hasil normal. Imbal hasil normal merupakan imbal hasil yang diharapkan (expected return) atau imbal hasil yang diharapkan oleh investor. Dengan demikian imbal hasil tidak normal (abnormal return) adalah selisih antara imbal hasil sesungguhnya yang terjadi dengan imbal hasil ekspektasi (Jogiyanto, 2010:94).

Abnormal Return (AR) akan terjadi jika return yang sesungguhnya (actual return)diterima investor berbeda dengan return yang diharapkan (expected return) oleh investor. Apabila return yang diterima oleh investor lebih besar dari return yang diharapkan, maka abnormal return-nya positif, dan sebaliknya, abnormal return dikatakan negatif jika return sesungguhnya yang diterima investor lebih rendah dari return yang diharapkan. Actual return dihitung dengan persentase kenaikan/penurunan harga saham pada suatu periode tertentu terhadap harga di periode sebelumnya.

\section{Pemecahan Saham}

Horne mendefenisikan pemecahan saham atau stock split sebagai berikut: "Stock split is an increase in the number of shares outstanding byreducing the par value of the stock. With a stock split, the number ofshares is increased through a proportional reduction in the par value ofthe stock".

Menurut Fahmi dan Hadi (2009: 107), tujuan perusahaan melakukan pemecahan saham adalah menghindari harga saham yang terlalu tinggi sehingga memberatkan publik untuk membeli/memiliki saham tersebut, mempertahankan tingkat likuiditas saham, menarik investor yang berpotensi besar guna lebih banyak memeiliki saham tersebut, menarik investor kecil untuk memiliki saham tersebut karena jika terlalu mahal maka kepemilikan dana dari investor kecil tidak akan sanggup menjangkau, menambah jumlah saham yang beredar, memperkecil risiko yang akan terjadi, terutama bagi investor yang ingin memiliki saham dengan harga saham yang rendah, dan menerapkan diversifikiasi investasi.

\section{Kerangka Pemikiran}

Kerangka pemikiran penelitian ini secara sistematis dapat digambarkan seperti berikut ini:

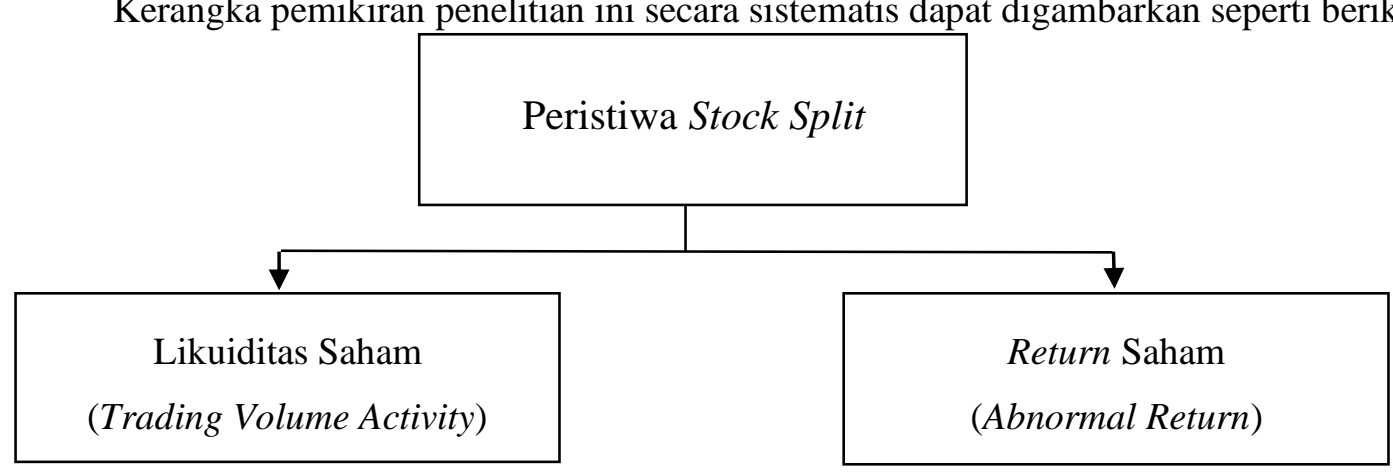




\section{JURNAL AKUNTANSI, Vol. 8, No. 2, November (2019)}

\section{Pengembangan Hipotesis}

Berdasarkan kerangka pemikiran yang telah diuraikan diatas, maka diajukan dua hipotesis dalam penelitian ini yaitu:

$\mathrm{Ha}_{1}$ : terdapat perbedaan likuiditas saham sebelum dan sesudah pemecahan saham

$\mathrm{Ha}_{2}$ : terdapat perbedaan abnormal return saham sebelum dan sesudah pemecahan saham

\section{METODE PENELITIAN}

Desain Penelitian

Metode yang akan digunakan dalam penelitian ini adalah penelitian komparatif. Populasi dalam penelitian ini adalah emiten yang terdaftar di Bursa Efek Indonesia (BEI) yang melakukan pemecahan saham tahun 2017-2018 sejumlah 34 perusahaan. Teknik sampel yang digunakan dalam penelitian ini adalah purposive sampling atau pemilihan sampel dengan kriteria-kriteria tertentu. Kriteria yang digunakan adalah emiten tidak melakukan corporate action lain pada saat bersamaan dengan stock split.

Perusahaan yang melakukan corporate action lain yakni membagikan dividen yaitu sebanyak 6 perusahaan dan dikeluarkan dari sampel, sehingga total sampel yang menjadi objek penelitian adalah sebanyak 28 perusahaan.

Tabel 1

Daftar Sampel Emiten yang Melakukan Pemecahan Saham

\begin{tabular}{|c|c|c|c|}
\hline No. & Tahun & Rasio Pemecahan & Jumlah \\
\hline 1 & \multirow{5}{*}{2017} & 2 & 3 \\
\hline 2 & & 4 & 2 \\
\hline 3 & & 5 & 8 \\
\hline 4 & & 8 & 1 \\
\hline 5 & & 10 & 4 \\
\hline 6 & \multirow{3}{*}{2018} & 2 & 4 \\
\hline 7 & & 5 & 5 \\
\hline 8 & & 8 & 1 \\
\hline
\end{tabular}

Sumber: www.idx.co.id

Tahapan uji yang dilakukan adalah :

\section{Uji Normalitas}

Uji normalitas bertujuan untuk menguji data berdistribusi normal atau tidak normal. Wati (2018) menyatakan bahwa keputusan dapat diambil dengan dasar probabilitas (Asymtotic Significance) yaitu:

- Jika probabilitas $>0,05$ maka data terdistribusi normal

- Jika probabilitas $<0,05$ maka data terdistribusi tidak normal

Untuk menguji normalitas data, digunakan uji Kolmogorov Smirnov Test untuk setiap variabel yang diteliti. Apabila berdasarkan uji normalitas diketahui bahwa data terdistribusi secara normal, maka statistik uji yang digunakan untuk melakukan uji hipotesis adalah Paired Sample T-Test, dan apabila data terdistribusi tidak normal, maka uji statistik yang digunakan adalah Wilcoxon Signed Rank Test. 


\section{JURNAL AKUNTANSI, Vol. 8, No. 2, November (2019)}

\section{Uji Hipotesis}

Analisis statistik uji beda digunakan dalam penelitian ini. Untuk membuktikan ada atau tidaknya dampak signifikan pemecahan saham terhadap likuiditas saham dan abnormal return pada periode sebelum dan sesudah stock split. Uji ini dilakukan dengan Wilcoxon Signed Rank Test.

Wilcoxon Signed Rank Test adalah uji nonparametris untuk mengukur signifikansi perbedaan antara 2 kelompok data berpasangan berskala ordinal atau interval tetapi berdistribusi tidak normal. Uji Wilcoxon Signed Rank merupakan uji alternatif dari uji pairing t test atau $t$ paired apabila tidak memenuhi asumsi normalitas. Uji ini dikenal juga dengan istilah Wilcoxon Match Pair Test. berikut:

Rumus uji Wilcoxon Signed Rank Testmenurut Cooper \& Schindler (2014:613) adalah sebagai

$$
z=\frac{T-\mu T}{\sigma T}
$$

Keterangan:

$\mathrm{T}$ : Jumlah rank dengan tanda paling kecil

$$
\begin{aligned}
& \mu T=\frac{n(n+1)}{4} \\
& \text { dan } \\
& \sigma T=\sqrt{\frac{n(n+1)(2 n+1)}{24}}
\end{aligned}
$$

Dasar pengambilan keputusan untuk menerima atau menolak hipotesis pada uji Wilcoxon Signed Rank Test sebagai berikut:

- Jika probabilitas (Asymp.Sig) $<0,05$ maka Ho ditolak artinya terdapat perbedaan.

- Jika probabilitas (Asymp.Sig) > 0,05 maka Ho diterima artinya tidak terdapat perbedaan.

\section{HASIL PENELITIAN DAN PEMBAHASAN Statistik Deskriptif}

Tabel 2

Hasil Analisis Deskriptif Rata-rata TVA dan AR5 Hari Sebelum dan 5 Hari Setelah PeristiwaStock Split

\begin{tabular}{lccccc} 
Variabel & $\mathbf{N}$ & Minimum & Maximum & Mean & Std. Deviation \\
\hline TVA sebelum & 28 & 0.0000 & 0.0234 & 0.0055 & 0.0081 \\
TVA setelah & 28 & 0.0000 & 0.0112 & 0.0012 & 0.0022 \\
AR sebelum & 28 & -0.0136 & 0.0516 & 0.0052 & 0.0133 \\
AR sesudah & 28 & -0.0283 & 0.1139 & 0.0069 & 0.0248 \\
\hline
\end{tabular}

Sumber: Data diolah (2019)

Pada variabel TVA, nilai minimum pada periode sebelum peristiwa pemecahan saham adalah sebesar 0.0000, nilai maksimum adalah sebesar 0.0234, mean sebesar 0.0055, dengan standar deviasi 


\section{JURNAL AKUNTANSI, Vol. 8, No. 2, November (2019)}

sebesar 0.0081. Nilai minimum rata-rata TVA pada periode sesudah peristiwa adalah sebesar 0.0000 , nilai maksimum adalah sebesar 0.0112, mean sebesar 0.0012, dengan standar deviasi sebesar 0,0022..

Nilai minimum variabel abnormal return pada periode sebelum peristiwa stock split adalah sebesar -0.0136, nilai maksimum sebesar 0.0516, mean sebesar 0.0052, dengan standar deviasi sebesar 0.0133. Nilai minimum variabel abnormal return sesudah peristiwa stock split adalah sebesar -0.0283 , nilai maksimum sebesar 0.1139, mean sebesar 0.0069, dengan standar deviasi sebesar 0.0248.

Nilai rata-rata variabel TVA dan AR sesudah peristiwa stock split berbeda apabila dibandingkan dengan rata-rata sebelum peristiwa, hal ini menunjukkan bahwa terdapat pengaruh peristiwastock split terhadap variabel TVA dan AR.

\section{Uji Asumsi}

Metode yang digunakan untuk uji normalitas data dalam penelitian ini adalah uji Kolmogorov Smirnov Test. Penentuan normalitas distribusi suatu data dengan menggunakan metode Kolmogorov Smirnov Test beracuan pada kaidah berikut:

a. Jika $\mathrm{P}$ value $>0,05$ maka data berdistribusi normal.

b. Jika $P$ value $<0,05$ maka data berdistribusi tidak normal

Setelah dilakukan uji normalitas terhadap data diatas dengan menggunakan aplikasi SPSS, gambargambar dibawah merupakan hasil yang didapatkan dari output aplikasi tersebut.

Tabel 1. Uji Normalitas Nilai TVA

One-Sample Kolmogorov-Smirnov Test

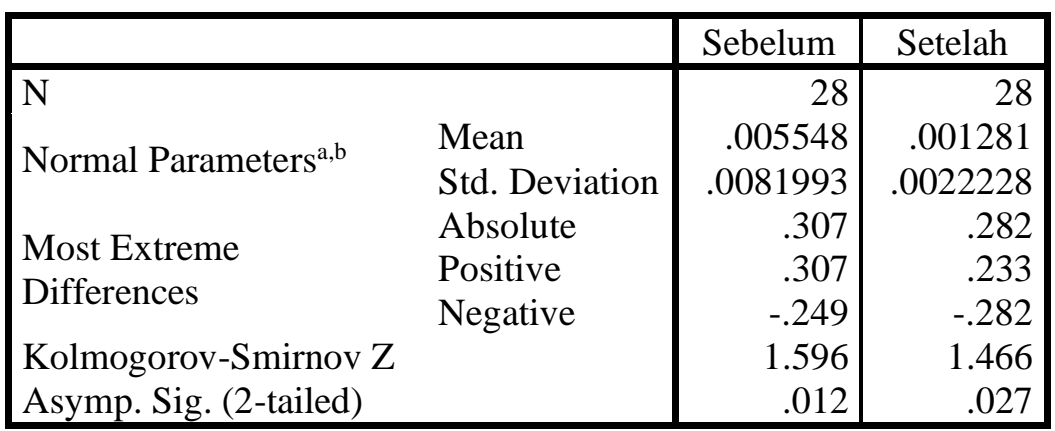

a. Test distribution is Normal.

b. Calculated from data.

Sumber: Data diolah (2019)

Dari output aplikasi SPSS tersebut terlihat bahwa baik data sebelum maupun sesudah pemecahan saham memiliki P value $(0,023$ dan 0,027$)<0,05$. Hal ini berarti, data tidak terdistribusi secara normal. Untuk itu, metode pengujian hipotesis yang akan digunakan adalah Wilcoxon Signed Rank Test. 
Tabel 2. Uji Normalitas Terhadap Nilai AR One-Sample Kolmogorov-Smirnov Test

\begin{tabular}{|ll|r|r|}
\hline & & Sebelum & \multicolumn{1}{c|}{ Setelah } \\
\hline $\mathrm{N}$ & & 28 & 28 \\
Normal Parameters ${ }^{\mathrm{a}, \mathrm{b}}$ & Mean & .005289 & .007304 \\
& Std. Deviation & .0133875 & .0248471 \\
Most Extreme & Absolute & .155 & .267 \\
Differences & Positive & .155 & .267 \\
& Negative & -.086 & -.143 \\
Kolmogorov-Smirnov Z & & .804 & 1.389 \\
Asymp. Sig. (2-tailed) & & .538 & .042 \\
\hline
\end{tabular}

a. Test distribution is Normal.

b. Calculated from data.

Sumber: Data diolah (2019)

Gambar diatas menunjukkan bahwa pada nilai rata-rata abnormal return setelah peristiwa pemecahan saham, $P$-value $(0,042)$ memiliki nilai yang lebih rendah dari 0,05 sehingga disimpulkan data tidak terdistribusi secara normal. Hal ini berarti, uji hipotesis yang akan digunakan terkait dengan abnormal return adalah metode Wilcoxon Signed Rank Test.

Setelah dilakukan uji beda terhadap nilai rata-rata TVA dengan metode Wilcoxon Signed Rank Test menggunakan aplikasi SPSS, didapatkan hasil berikut ini:

\begin{tabular}{|ll|r|r|r|}
\hline & Ranks \\
\hline & Negative Ranks & $20^{\mathrm{a}}$ & 12.73 & 254.50 \\
& Positive Ranks & $3^{\mathrm{b}}$ & 7.17 & 21.50 \\
Sesudah - Sebelum & $5^{\mathrm{c}}$ & & \\
& Ties & 28 & & \\
& Total & & \\
\hline
\end{tabular}
a. Sesudah $<$ Sebelum
b. Sesudah $>$ Sebelum
c. Sesudah $=$ Sebelum 


\section{JURNAL AKUNTANSI, Vol. 8, No. 2, November (2019)}

Tabel 3. Uji Beda Nilai Rata-rata TVA

Sebelum dan Sesudah Pemecahan

Saham.

Test Statistics ${ }^{\mathrm{a}}$

\begin{tabular}{|l|r|}
\hline & \multicolumn{1}{|c|}{$\begin{array}{c}\text { Sesudah - } \\
\text { Sebelum }\end{array}$} \\
\hline $\begin{array}{l}\text { Z } \\
\text { Asymp. Sig. (2- } \\
\text { tailed) }\end{array}$ & $-3.547^{\mathrm{b}}$ \\
\hline
\end{tabular}

a. Wilcoxon Signed Ranks Test

b. Based on positive ranks.

Sumber: Data diolah (2019)

Dari hasil diatas terlihat bahwa secara rata-rata terdapat perbedaan likuiditas saham setelah pemecahan saham, dan jika dilihat dari nilai Sum of Ranks, perubahan yang terjadi adalah negatif, terlihat dari nilai Negative Ranks yang jauh lebih besar dari Positive Ranks. P value menunjukkan nilai yang lebih rendah dari 0,05 yaitu 0,00 , hal ini berarti, tingkat likuiditas saham sebelum dan sesudah pemecahan saham secara rata-rata berbeda secara signifikan. Dengan begitu, hipotesis diterima.

Untuk membuktikan hipotesis kedua yang menyatakan bahwa terdapat perbedaan abnormal return saham sebelum dan sesudah pemecahan saham, maka akan dilakukan uji beda terhadap variabel abnormal return dengan menggunakan uji Wilcoxon Signed Rank Test.

Berikut ini adalah hasil output dari aplikasi SPSS yang didapatkan setelah dilakukan uji bedaWilcoxon Signed Rank Test pada nilai rata-rata abnormal return sebelum dan sesudah pemecahan saham:

\begin{tabular}{|rl|r|r|r|}
\hline & Ranks \\
\hline & Negative Ranks & $14^{\mathrm{a}}$ & Mean Rank & Sum of Ranks \\
\hline \multirow{3}{*}{ Setelah - Sebelum } & 13.15 & 171.00 \\
& Positive Ranks & $14^{\mathrm{b}}$ & 14.79 & 207.00 \\
& Ties & $0^{\mathrm{c}}$ & & \\
& Total & 28 & & \\
\hline
\end{tabular}

a. Setelah < Sebelum

b. Setelah $>$ Sebelum

c. Setelah $=$ Sebelum

Test Statistics ${ }^{\mathrm{a}}$

\begin{tabular}{|l|r|}
\hline & \multicolumn{1}{|c|}{$\begin{array}{l}\text { Setelah }- \\
\text { Sebelum }\end{array}$} \\
\hline$Z$ & $-.432^{\mathrm{b}}$ \\
$\begin{array}{l}\text { Asymp. Sig. (2- } \\
\text { tailed) }\end{array}$ & .665 \\
\hline
\end{tabular}

a. Wilcoxon Signed Ranks Test

b. Based on negative ranks.

Sumber: Data diolah (2019) 


\section{JURNAL AKUNTANSI, Vol. 8, No. 2, November (2019)}

Hasil pengujian diatas menunjukkan bahwa secara keseluruhan, terjadi peningkatan abnormal return pada pasar.Namun, berdasarkan nilai $p$-value yang didapatkan yaitu sebesar 0,665 , artinya nilai $p$ value $>0,05$, kesimpulan yang didapat adalah bahwa peristiwa pemecahan saham tidak berpengaruh signifikan terhadap nilai abnormal return secara rata-rata semua saham. Dengan begitu, hipotesis ditolak.

\section{Pembahasan}

1) Hipotesis Pertama

Terdapat perbedaan rata-rata TVA antara sebelum dan sesudah peristiwa pemecahan saham dari 28 sampel perusahaan berdasarkan hasil penelitian. Jika dilihat dari nilai Sum of Ranks, perubahan yang terjadi adalah negatif, terlihat dari nilai Negative Ranks yang jauh lebih besar dari Positive Ranks. P value menunjukkan nilai yang lebih rendah dari 0,05 yaitu 0,00 , hal ini berarti, tingkat likuiditas saham sebelum dan sesudah pemecahan saham secara rata-rata berbeda secara signifikan. Penjelasan diatas menunjukkan bahwa terdapatperbedaan TVA sebelum dan sesudah peristiwa pemecahan saham, yang berarti hipotesis alternatif satu $\left(\mathrm{Ha}_{1}\right)$ diterima dan hipotesis nol $\left(\mathrm{H}_{0}\right)$ ditolak.

2) Hipotesis Kedua

Hasil penelitian menunjukkan bahwa dari 28 sampel perusahaan, terdapat perbedaan rata-rata AR antara sebelum dan sesudah peristiwapemecahan saham. Jika dilihat dari nilai Sum of Ranks, positive ranks lebih besar dari negative ranks, artinya secara keseluruhan, terjadi peningkatan abnormal return pada pasar.Namun, berdasarkan nilai $p$-value yang didapatkan yaitu sebesar 0,665 , artinya nilai $p$ value $>0,05$, dapat disimpulkan bahwa hipotesis alternatif dua $\left(\mathrm{Ha}_{2}\right)$ ditolak, yang berarti peristiwa pemecahan saham tidak berpengaruh signifikan terhadap nilai abnormal return secara rata-rata semua saham.

\section{PENTUP}

\section{Simpulan}

Berdasarkan hasil analisis uji beda dengan metode Wilcoxon Signed Rank Test, terlihat bahwa terdapat perbedaan likuiditas saham sebelum dan sesudah peristiwa pemecahan saham, terlihat dari perbedaan nilai trading volume activity-nya. Dengan $p$-value $<0,05$, artinya perbedaan yang terjadi dapat dikatakan signifikan. Dan dilihat dari nilai Sum of Ranks, perubahan yang terjadi didominasi oleh Negative Ranks, maka dapat disimpulkan bahwa, peristiwa pemecahan saham berpengaruh negatif secara signifikan terhadap tingkat likuiditas saham. Hasil output SPSS atas uji beda terhadap nilai abnormal return menunjukkan bahwa, terdapat perbedaan saham antara sebelum dan setelah pemecahan saham. Namun nilai $p$-value yang berada diatas 0,05 berarti bahwa pengaruh peristiwa pemecahan saham ternyata tidak signifikan terhadap saham secara keseluruhan. Perbedaan nilai abnormal return lebih banyak terjadi pada positive ranks, artinya terjadi peningkatan nilai. Sehingga dapat disimpulkan bahwa peristiwa pemecahan saham berpengaruh positif abnormal return saham namun tidak signifikan.

Saran bagi peneliti selanjutnya agar memperluas cakupan variabel dan proksi. Untuk dapat mengetahui apakah peristiwa pemecahan saham ini memiliki pengaruh terhadap saham, selain menilai likuiditas dan abnormal return-nya, dapat juga dipakai harga relatif saham. Untuk menilai likuiditas saham, selain menggunakan proksi TVA, dapat juga dipakai bid-ask spread. Objek penelitian ini masih kurang spesifik karena mencakup semua jenis perusahaan dan dengan ukuran yang bervariasi. Untuk penelitian selanjutnya, objek penelitian dapat lebih dispesifikkan dengan pertimbangan ukuran perusahaan maupun fase pertumbuhan perusahaan. Bagi emiten, disarankan agar lebih mempertimbangkan saat akan melakukan pemecahan saham. Pemecahan saham tidak selalu berdampak positif terhadap nilai saham di pasar. Khususnya terhadap nilai likuiditas dan abnormal return-nya. Informasi yang ingin disampaikan oleh emiten ke pasar tidak selalu disambut oleh reaksi pasar yang positif, dan peristiwa pemecahan saham ini tidak cukup untuk meningkatkan gairah dan minat pasar terhadap saham perusahaan. Hasil penelitian 


\section{JURNAL AKUNTANSI, Vol. 8, No. 2, November (2019)}

ini menunjukkan bahwa, justru pemecahan saham mendapat reaksi yang negatif terlihat dari nilai TVAnya yang menurun. Bagi Investor sebaiknya lebih berhati-hati saat mengambil keputusan investasi. Pemecahan saham tidak selalu menjadi momen yang tepat untuk mendapatkan keuntungan di atas normal maupun keuntungan di atas yang diharapkan (expected return). Pemecahan saham bukanlah sinyal yang kuat yang menandakan bahwa investor dapat mengambil kesempatan yang tepat untuk mendapatkan keuntungan lebih atas transaksi saham yang dilakukan.

\section{REFERENSI}

Astuti, A.R.T. (2012). Analisis Pengaruh Stock Split Terhadap Harga Saham Perusahaan yang Terdaftar di Bursa Efek Indonesia. Skripsi, Universitas Hasanuddin: Makassar. (Tidak dipublikasikan).

Astuti, D. W. (2015). Dampak Stock Split Terhadap Likuiditas Saham. Skripsi. Universitas Negeri Yogyakarta: Yogyakarta. (Tidak dipublikasikan).

Budi, S. \& Lidharta, P.D. (2011). Analisis Perbedaan Kinerja Keuangan Sebelum dan Sesudah Stock Split pada Perusahaan yang Terdaftar di Bursa Efek Indonesia.Jurnal Spread. Vol. 1, No. 1, April 2011: $62-73$.

Cooper, D.R. and Schindler, P.S. (2014). Business Research Methods. 12th ed. McGraw-Hill:New York.

Fahmi, et al. (2009).Teori Portofolio dan Analisis Investasi. Alfabeta: Bandung.

Fahmi, I. (2015). Pengantar Manajemen Keuangan Teori dan Soal Jawab. Alfabeta: Bandung.

Fortuna, C.H.R. (2010). Analisis Pengaruh Stock Split Terhadap Harga Saham pada Perusahaan Go Public di Bursa Efek Indonesia. Skripsi. Universitas Diponegoro: Semarang. (Tidak dipublikasikan).

Hadi, N. (2013). Pasar Modal. Graha Ilmu: Yogyakarta.

Hartono, J. (2010) Teori Portofolio dan Analisis Investasi. Edisi Ketujuh. BPFE: Yogyakarta.

Hartono, J. (2013). Teori Portofolio dan Analisis Investasi. Edisi Kedelapan. BPFE: Yogyakarta.

Hendrawijaya, M.D. (2009). Analisis Perbandingan Harga Saham, Volume Perdagangan Saham, dan Abnormal Return Saham Sebelum dan Sesudah Pemecahan Saham (Studi pada perusahaan go public yang melakukan pemecahan saham antara tahun 2005-2008 di BEI). Tesis. Universitas Diponegoro: Semarang. (Tidak dipublikasikan).

Hidayat, A. (23 Maret 2017). Tutorial Cara Uji Wilcoxon Signed Rank Testhttps://www.statistikian.com/2014/07/tutorial-uji-wilcoxon-signed-rank-test.html/amp

Irianto, A. (2010). Statistika Konsep, Dasar, Aplikasi, dan Pengembangannya. Kencana Prenada Media Group: Jakarta.

Izza, F. N. (2016). Analisis Pengaruh Stock Split TerhadapLikuiditas Saham dan FutureProfitability Perusahaan. Skripsi. Universitas Negeri Yogyakarta: Yogyakarta. (Tidak dipublikasikan).

Jones, C.P.(2014). Investment Principles and Concepts. Twelfth Edition. John Wiley and Sons Singapore Pte. Ltd: Singapura.

Kasmir. (2016). Analisis Laporan Keuangan. Raja Grafindo Persada: Jakarta. 
Ruslianti, E. \& Farida, E.N. (2010). Pemecahan Saham Terhadap Likuiditas dan Return Saham. Jurnal Bisnis dan Akuntansi Vol. 12, No. 3.

Siregar, S. (2011). Statistika Deskriptif Untuk Penelitian. PT Raja Grafindo Persada; Jakarta.

Sunarto \& Riduwan. (2014). Statistika Untuk Penelitian. Alfabeta: Bandung.

Syahyunan. (2015).Manajemen Keuangan 1. Edisi ketiga. USU press: Medan.

Tandelilin, E. (2010). Portofolio dan Investasi. Kanisius: Yogyakarta.

Tim Studi BAPEPAM-LK. (2011). Volatilitas Pasar Modal Indonesia dan Perekonomian Dunia. Kementerian Keuangan: Jakarta.

Utami, T.N., Maski, G. \& Idrus, H.M.I. (2009). Dampak Pengumuman Stock Split Terhadap Return, Variabilitas Tingkat Keuntungan dan Aktivitas Volume Perdagangan Saham (Studi pada Perusahaan Manufaktur yang Terdaftar di BEJ Tahun 1997-1999). Wacana Vol. 12 No. 4.

Wati, L.N. 2018. Metodologi Penelitian Terapan dengan Aplikasi SPSS, EVIEWS, SmartPLS, dan AMOS. Jakarta: Pustaka Amri.

Widjanarko, I. (2012). Analisis Pengaruh Pemecahan Saham (Stock Split) Terhadap Likuiditas Saham Dan Return Saham. Skripsi Universitas Diponegoro: Semarang. (Tidak dipublikasikan). 